\title{
Democracy and Digital Dissonance: The Co-Occurrence of the Transformation of Political Culture and Communication Infrastructure
}

\author{
प⿴囗十口प \\ Barbara Pfetsch \\ ORCID: 0000-0003-4655-663X \\ FREIE UNIVERSITY OF BERLIN, GERMANY \\ https://doi.org/10.19195/1899-5101.13.1(25).7
}

\begin{abstract}
The aim of this essay is to discuss the state of democracy in Western Europe in the light of an essential change in public spheres towards more dissonance, disconnection, and noise. It is argued that this condition is the unintended consequence of the co-occurrence of two long-term changes in contemporary societies: political culture changes in liberal democracy and changes in communication infrastructures. The interaction of the disruption of democracy and digital communication has implications for public spheres as opportunity structures for democratic speech and institutions. The dynamics of dissonant public spheres have created a new disinformation order, pushing new political actors and communication modes to the fore. These conditions threaten established patterns of authoritative information flows and public debate, which puts contemporary democracy under serious stress.
\end{abstract}

KEYWORDS: democracy, digital public sphere, political communication, public debate, information flows.

\section{ㅁㅁㅁㅁㅁำ}

\section{INTRODUCTION}

There are plenty of occasions that urge scholars to reconsider the current state of public communication in liberal democracy and the fundamental paradigms of deliberation therein. On the surface, we notice changes in the practices and modes of political communication. Politicians, nowadays, prefer the microblogging service, Twitter, to spread their messages instead of talking to journalists. At second glance, we observe that authoritative channels of news and information, such as public television and the quality press, are challenged by the algorithms of commercial search engines and digital platforms. We have also realized that media professionalism and media freedom, even in parts of Europe, are no longer a given 
but have come under pressure by semi-authoritarian governments and right-wing populist groups simultaneously. These developments collectively indicate the essential transformation of the public sphere in liberal democracy towards a dissonant, disconnected, and noisy mode of political communication.

The argument elaborated in this essay is that this transformation can be seen as an (unintended) consequence of two larger long-term changes taking place in the political culture and communication infrastructures. Digitalization and the changes in the media have contributed to a fragmentation of audiences, while at the same time the political culture is characterised by declining trust in democratic institutions. In hybrid media systems, dissonant public spheres are spaces of disconnection filled by new actors, new structures, and new modes of public communication. The consequences of these changes are the breakdown of former authoritative flows of information and a deprofessionalization of journalism, as well as the hollowing out of democratic institutions through commercial interests, populist groups, and foreign interventions. All of these developments put liberal democracy under stress as the capability of democratic will formation and the mediation of public opinion are hampered. For scholars of political communication, new research questions are emerging, and we must analyse the coping strategies of parties, governments, movements, media, and audiences and its consequences for democracy.

\section{CHANGES IN POLITICAL CULTURE AND INFORMATION INFRASTRUCTURES}

The link between democracy and communication is ingrained in the underlying cultural and attitudinal foundations of democratic systems. How political institutions work and how they perform depends on the functioning of the communication between political actors and citizens and how well democratic norms and values are present in public communication and internalized by the people. Starting with a diagnosis of the problems of contemporary democracy, we need to scrutinise the state of political culture and the changes in communication infrastructures.

\section{Deconsolidation of democracy}

According to the idea of political culture, democratic systems depend on whether people have internalized fundamental values of democratic conduct and support democratic institutions. Hence, there is something wrong with democracy if people's attitudes are alienated from the idea of democratic rule and democratic institutions. Recent studies (Foa \& Mounk, 2016; 2017) point to striking signs of deconsolidation in so-called Western democracies. The crisis can be measured using three indicators (Foa \& Mounk, 2016, p. 15): (a) the degree to which anti-system parties and movements emerge; (b) the degree of popular support for democracy as a system of government; and (c) the degree to which democratic rules are accepted. 


\section{(a) The emergence of anti-system parties}

A recent study by Kriesi and Hutter (2019) demonstrated that, during the last decade, European democracies have undergone a profound transformation of national political spaces, which have been expressed in new conflicts and cleavage structures. These changes enabled the rise of new challenger parties, which, in almost all countries, have threatened the order of the mainstream political parties. Hutter and Kriesi (2019) linked the development to new conflicts in the aftermath of long-term cultural and value changes in post-industrial societies, on the one hand, and globalization and denationalization, on the other hand. Furthermore, the economic crisis in 2008/2009 fuelled the political crisis and enhanced the reconfiguration of national party systems. These developments have played out differently in European regions. The democracies in Northern and Western Europe have witnessed the continual erosion of mainstream parties and the loss of voters to often populist challenger parties which mobilized citizens who felt neglected from the political mainstream. Also, these countries faced the decline of the traditional class cleavage. In other words, the moderate left has been moving to the right, while the moderate right has been moving to the left (Kriesi \& Hutter, 2019). In the United Kingdom (UK), as well as in Germany, the reshuffling of political conflict resulted in a "crisis of representation" (Bremer \& Schulte-Cloos, 2019, p. 360) in which mainstream parties suffered from an increasing remoteness from their constituencies and a decline of mobilizing capacity. The rise of populist parties increased the politicization of cultural issues and strengthened intra-party disagreement. The crises appeared in a different constellation in Southern Europe, characterised by weaker Euroscepticism and the mobilization of populist features on the left instead of the right. In Eastern European countries however, the mainstream parties have taken advantage of the value change and are catering to the fear of globalization by enhancing a defensive form of nationalism. There are also high levels of political conflict and the mobilization of cultural issues and identity politics, which threaten the democratic order.

\section{(b) Popular support for democracy}

The changes in the institutional setup of Western democracies have been accompanied by declining levels of trust. Thus, Foa and Mounk (2016, p. 7) found:

Citizens in a number of supposedly consolidated democracies in North America and Western Europe have not only grown more critical of their political leaders. Rather, they have also become more cynical about the value of democracy as a political system, less hopeful that anything they do might influence public policy, and more willing to express support for authoritarian alternatives.

In political culture research, the decline in support for democracy is measured using various indicators. According to the analysis of the World Value Survey data for the European Union by Foa and Mounk (2016, pp. 9-15), attitudes towards 
liberal institutions have deteriorated over the last decade, while support for military rule or strong leadership has risen. Moreover, what is most puzzling is the "quickly widening generational gap in political apathy" (Foa \& Mounk, 2016, p. 10), meaning that the cohort of 16 to 25 -year-olds was considerably less supportive of democratic values such as civil rights and free elections and they were also less interested in politics. Interestingly enough, the previous pattern that younger generations compensate for their lower formal participation in elections by higher levels of nonconventional political activities no longer holds true either, since participation in new social movements has also declined among younger generations (Foa \& Mounk, 2016, p. 11).

\section{(c) Acceptance of democratic rules}

In another analysis, Foa and Mounk (2017, pp. 6-7) show that disaffection with the democratic order and scepticism towards liberal institutions have become more widespread among younger generations in established democracies, as well as in some EU countries, such as Germany and France. The authors linked the rise of populist leaders in Poland, Hungary, Austria, and France as well as in the United States (US) and Venezuela to such changes. They surmised that, contrary to textbooks on political science, the stability of consolidated democracy is being threatened, while formerly unacceptable authoritarian alternatives of government are no longer contested, even in Europe. Foa and Mounk (2017, p. 14) concluded that, "the process of deconsolidation now taking place across most liberal democracies is a very serious warning sign". Fuchs and Roller (2019) were more cautious in their interpretation, but they also found evidence for the erosion of the legitimacy of democracy in some EU crisis countries. Moreover, it is not only the idea of democracy that is suffering from a decrease of support. Studies have shown that trust in political institutions among EU citizens has been low or decreasing over time; only one-third of citizens have trust in their national government and parliament, and the political parties have achieved even lower trust rates (Europäische Kommission, 2018, p. 43).

Scholars have interpreted their findings on the deconsolidation of democracy as a cultural backlash from rejecting liberal and cosmopolitan values, which plays out in identity politics, xenophobia, and preferences for authoritarian leadership (Inglehart \& Norris, 2016, p. 15). For instance, in EU countries, hostile attitudes towards migrants are an essential determinant of dissatisfaction with democracy; the more people feel threatened by the negative consequences of immigration, the less satisfaction they express with democracy (Fuchs \& Roller, 2019, p. 242). Antiimmigrant attitudes go hand in hand with preferences for a strong leader and increasing support for autocratic leadership (Fuchs \& Roller, 2019, p. 243), mistrust of global and national governance, and political polarization. Fuchs and Roller (2019, p. 244) warned that the potential for authoritarian leadership could be exploited by populist parties. In the same vein, Norris and Inglehart (2016) docu- 
mented the rise of authoritarian populism in Western Europe and in the young democracies of Eastern Europe.

In their analysis of the disruption of democracy, political scientists focus on political culture, the rise of new cleavages, and cultural backlash from value changes. However, they easily ignore that any political expression and democratic practice is dependent on how it is communicated to the public. Hence, in the light of long-term crisis of democracy, one also needs to focus on the long-term changes in the conditions of public communication.

\section{COMMUNICATION INFRASTRUCTURES: HYBRID MEDIA SYSTEMS}

The infrastructure of political communication has also undergone long-term changes, which we can distinguish using the typology of Blumler and Kanavagh (1999) and Blumler (2013), who spoke of "four ages of political communication". While the first stage was characterised by a dominant pattern of traditional party and government communication with strong voter loyalties, the second age was driven by television as the main channel of political communication and the professionalization of election campaign communication and the formatting of news. In the 2000 s, political communication reached the third age, which was signified by the multi-channel public; the pluralization and commercialization of television; the introduction of the Internet; and the professionalization of political marketing, media consulting, and political news management. Finally, the fourth age, which began in 2010, has been a period of all-encompassing communication abundance set off by the affordances of Web 2.0, which entails an enormous increase in complexity (Blumler, 2015). At the same time, public and quality media have lost their legitimacy as the dominant media of political communication. Digitalization penetrates all aspects of the technical, institutional, and social infrastructures of public communication. As such, a completely new infrastructure of communication has evolved, challenging the established foundations and functions of traditional mass media. Needless to say, the study of political communication can no longer be restricted to legacy media only as the infrastructure of public debate.

This idea was taken up nicely in the theorizing of Andrew Chadwick's writings, which referred to the interaction of old and new media in political communication and the emergence of a "hybrid media system" (2013). Chadwick (2011, 2013) argued that the interaction of legacy media and digital media refers to their technologies, genres, norms, behaviors, and organizations, collectively producing a hybrid media system composed of multiple, loosely-coupled actors, groups, and sites. In addition to traditional media actors, independent news creators temporarily involve themselves in the newsmaking process, often simultaneously. The emergence of the hybrid media system repositioned traditional media vis-à-vis online media and social networks within public communication and changed the contexts and dynamics of political communications. Chadwick (2011) demonstrated that 
traditional media integrated non-elite actions and information from social media, digital platforms, and blogs into their own production practices and routines. In fact, there is evidence that weblogs and newspapers increasingly cite each other as news sources (Messner \& Distaso, 2008) and mutually influence each other (Lee, 2015). New dynamics of agenda building and political mobilization have emerged (Pfetsch, Miltner, \& Maier, 2016; Abdi-Herrle, 2018), and political elites have lost their exclusive position as news sources.

The hybrid media system has made the interaction of political actors and traditional mass media more complex. The infrastructure of public and political information has become more diverse, differentiated, and volatile and less well organized. Even if we uphold that established mass media are still the predominant counterparts of political actors, we must acknowledge that additional and parallel information ecologies (Häussler, 2019) have developed outside the traditional communication infrastructure. A vast multitude of channels and a high dispersion of actors have emerged. They are fundamentally different in their structures and processing of public debate, and they nourish a dynamic economy of attention in the overall society (Hindman, 2008). Through cost reductions and permanent changes of roles in the production and consumption of information, the amount of information has grown enormously, but the attention of the audience must be shared. This condition has led to fluid roles, forms of information production, and linkages between producers and audiences. This heterogeneity encourages new forms of disintermediation and, at the same time, enhances the fragmentation and segmentation of audiences. Most importantly, we must not forget that social media platforms, by their very nature, are commercially-driven advertisement tools where user data and attention are traded for commercial clients.

\section{ON THE NATURE OF THE PUBLIC SPHERE: FROM DELIBERATION TO AGONISTIC PLURALISM AND FROM CONSENSUS TO DISSONANCE}

The transformation of democratic political culture and the changes in the public communication infrastructure come together in the reconfiguration of the public sphere. In social theory, the public sphere denotes the arena within which communication channels for citizens are provided and used to publicly express their views on issues of society (Van Dijk \& Hacker, 2018, p. 82). In distinction to public space, the public sphere concept is strongly linked to the writings of Habermas (1996, 2006) who sought a space to deliberate the best possible solutions for issues and find a binding consensus. The concept carries a normative notion, as the public sphere is not only a functional system of society with flows of information and communication to be shared, but, more importantly, it is also a forum of intermediation "between formally organized and informal face-to-face deliberations in arenas both at the top and at the bottom of the political system" (Van Dijk \& Hacker, 2018, p. 83). Habermas (2006) underlined the role of the quality press in organizing public debate 
and acting to sort out public communication. However, considering the fundamental changes in the infrastructure of communication and the advent of digital media and social networks, scholars have stated that the Habermasian model of the public sphere "is no longer valid" (Van Dijk \& Hacker, 2018, p. 90).

Instead of a deliberative forum, the public sphere is actually characterised by the co-existence of many issue publics and by ruptures, contradictions, and contentions acted out in multiple public debates. Thus, theories of the public sphere put forward by authors, such as Mouffe (2000) and Downey and Fenton (2003), acknowledged its complex and potentially conflictual nature and stressed the visibility of ruptures more than the normative goal of consensus (Downey \& Fenton, 2003 , p. 195). In this perspective, the public sphere displays the conflicts resulting from marginalization and expropriation, racism, political polarization, and crises and also enables the constitution of counter-publics.

If the main features of hybrid media systems in digital infrastructures are large numbers of dispersive voices, polyvocality, and contestation, then they play out as "dissonant public spheres" (Pfetsch, Löblich, \& Eilders, 2018). The term dissonance alludes to music theory and the nature of polyvocality, incompatible sounds, and shrill disharmony, which violate the audience's desire for chromatic harmony. Also, as real world communication examples, such as Donald Trump's tweets or the Brexit campaigns, show, dissonant public spheres abstain from rational arguments or references to others. They do not aspire to understand, deliberate, or seek consensus. Instead, we may observe increasing levels of noise, fractured actor constellations, parallel issue agendas, divergent or contradictory opinions, or fundamental conflicts over substantial problems (Waisbord, 2016).

As digitalization and social media penetrate society more deeply, the nature of the communication infrastructure must be seen as the main driver of dissonance in public spheres. The driver potential of the Internet, and especially Web 2.0, is ascribed to its technical potential (which goes beyond the options of classical broadcasting and the press) and its social appropriation (Benkler, 2006; Neuberger, 2009). Both aspects have led to an ongoing increase in the volume and differentiation of content (Benkler, 2006; Neuberger, 2009). Thus, we may expect ever more polyvocality and plurality of actors, issues, opinions, and audience options. Dahlgren (2005, p. 151) refers to this situation as "a cacophony" of public voices and "too much dispersion and polyvocality".

Revolving around the conditions of digital communication is an argument about the benefits of networks and their power as a "ubiquitous connector of politics, economics, societies, cultures, information, audiences, content, and organizations" (Waisbord, 2016, p. 2). For instance, Benkler (2006, p. 247) maintained that networked public spheres are more responsive and more diverse than mass media because they "provide broader intake, participatory filtering, and relatively incorruptible platforms for creating public salience". Contrary to scholarship on media connectivity, Waisbord (2016, pp. 2-3) argued that this perspective overlooks 
the potential of disconnection and disintegration. In his view, "a world of mediated connections coexists with multiple disconnections" (Waisbord, 2016, p. 3), and, instead of integrating audiences and strengthening social ties, the Internet undermines communication across differences. In fact, the absence of connections between diverse publics emphasizes anti-communication dispositions that breed intolerance, apathy, and hatred. Moreover, sceptical accounts also point to the disparate short-term communication strategies of political elites (Napoli, 2010), as they are confronted with the speedy random interaction of digital media, online channels, and traditional media. It is most likely, then, that dissonant public spheres come with asymmetries in public debates, emerging on the basis of ideological cleavages or demographic imbalances, or play out in segmented issue publics (Berman \& Mulligan, 2003).

\section{(UNINTENDED) CONSEQUENCES}

The state of public and political communication in the dissonant public spheres emerging in contemporary Western countries has been highly volatile and dynamic, yet it can be seen as an unintended consequence of the interaction of the long-term changes in the communication infrastructure and liberal democracy. The technical affordances allow political and social actors, the commercial Internet industry, as well as individual actors and technologies, to strategically disrupt democratic functions. As the authoritative information flows in a media-driven environment slip into the hybridity of the digital media system, it becomes difficult for audiences to sort out messages as right or wrong or true or false. There are even fewer opportunities for citizens to single out messages manipulated by algorithms or created by artificial intelligence or bots.

In the meantime, the cacophony of multiple voices has become a permanent feature of public debate, which needs further scrutiny by scholars of political communication. The conditions and contexts of political communication in dissonant public spheres should be analyzed with respect to three dimensions (Toepfl \& Piwoni, 2015): (a) the actors and roles of the public sphere, (b) the practices and modes of communication, and (c) the spaces in which public communication takes place.

\section{Actors and roles in dissonant public spheres}

The emergence of dissonant public spheres means that public and political communication are no longer under the control of professional journalists and traditional media through their interactions with political elites. Instead, public debate is characterised by a multitude of new actors from the periphery; counter publics; and civil society actors, such as bloggers, network activists, citizen journalists, and lay people who publicly advocate their causes. New actor roles in public debate also include data breach hunters, digital consultants, and information software develop- 
ers. Furthermore, secondary performance roles adopted by bloggers and citizen journalists (Neuberger, 2014; Volkmann, 2010; Wendelin, 2014) are blurring the division between media performance (journalist) and audience (recipient).

The new divisions in communication roles challenge political elites' control of the political agenda and legacy media's public agenda setting function. Journalists lose their function as gatekeepers of public debate when audiences can directly interact via the Internet. Politicians, political organizations, and movements are not dependent on newsrooms anymore. Likewise, audiences and consumers can directly approach political parties and governments (Neuberger, 2009, p. 39).

The actor repertoire in political communication in dissonant public spheres is diverse and confusing, temporary, short-term, and opaque. Since actors, such as bloggers, online activists, online agencies, and the commercial Internet industry, are not bound to the professional and ethical norms of journalism, they may use their publicity resources, if not for manipulation, then for undue campaign intervention practices. With their outreach, speed, and numbers of clicks, they are in a position to counteract the traditional chains of information. As these actors are not held responsible like journalists, they operate using their own "media logic" (Altheide \& Snow, 1979) and speed and according to their own interests. This is particularly true for professional and technological intermediaries, the most successful of which are large economic players, such as search engines and news aggregators. The actor repertoire also includes foreign actors or actors from foreign bot factories who use bots or dark ads to interfere in national campaigns and to manipulate public opinion.

\section{Practices and modes of communication}

The noise level of dissonant public spheres help set the stage for the communication strategies of political elites (Napoli, 2010). Political coalitions are built via online issue networks hyperlinked around a particular political issue or social cause. Häussler (2019) argued that these networks must be seen as digital political communication ecologies of civil society, the media, and political interests around particular causes.

The disruptions of democratic political culture and emerging populism in dissonant public spheres not only entails noisy eruptions of public debate, fundamental hate speech, and ideological polarization, but also involves dubious information, rumors, and conspiracy campaigns (Bennett \& Livingstone, 2018). Thus, communication is open for manipulation and economic and political exploitation from dubious businesses, who, by hacking or buying social media data, may engage in dark advertising, microtargeting of messages, and political campaigns. For instance, the Cambridge Analytica case-including the pro-Brexit campaign, a database on registered voters, an organization funded by the Koch brothers, and the Donald Trump presidential campaign demonstrates how such a network is built on manipulation (House of Commons, 2019, p. 47). 


\section{Spaces of dissonant public spheres}

In the light of the existence of dissonant public spheres, in which the affiliations of actors are unclear and the audiences are ephemeral, we can no longer define a coherent political communication system. Thus, the space of political communication is mostly the virtual reality of the networked space. One of the main features of this communication relates to new and unpredictable connections, since those engaged in political communication do not necessarily know each other. The communicators operate on the web or with their own niche media or platforms, which are usually more specialized and focused on particular issues, as well as exclusionary politics.

The ubiquity of social networks and digital media create personalized alternative public spheres through which people share their own news and fabricated rumors. The weakening of traditional bases for validating information has opened societies to bots, trolls, hacking, and disinformation from outside sources. In addition, the manufacture of disinformation has become a business model to get likes, shares, and clicks on social media. This further complicates the challenges to legacy media institutions from the Internet industry. While media giants, such as Facebook, YouTube, and Google, struggle to police the distribution of misinformation and undue content, beyond academics, journalists, and activists, few citizens decry the decline of the mass media as an institution.

Traditional media must adapt to the changes in the public sphere by creating new business models and roles that cater to the speed and attention economy of clicktivism. As quality journalism is expelled from these roles, journalism in dissonant public spheres is subject to deprofessionalization and hollowing out. Many journalists lose their professional newsmaking function while catering to the social media strategies of their organizations.

The conditioning of the roles of journalism in public debate has reverberations in the media profession, as well as in the news business. As journalism is taking on a gate watching function (Bruns, 2005), it is losing its strong binding to professional newsmaking and journalistic norms of accuracy and truth. Journalists are part of the multiple actor repertoire, and, as communication in hybrid media systems is fast and unforeseeable, they need to react, while shorthanded, to the dynamics of the issue networks. This also means that there is hardly any time to research sources or check back information. An example of the pressures brought on by the dynamics of "real-time journalism" (Altmeppen et al., 2015, p. 387) was the terrorist attack in Paris when media reporting lost its connection to research and reliable sources in the fluid public attention economy, which operates based on heavy competition among many information suppliers.

A new feature of political communication, which has only become possible through the affordances of digital communication, is that foreign actors become directly involved in national political communication. The Cambridge Analytica case documented that the agency of manipulation, the SCL Group, was part of an 
international network of US and Russian actors who interfered directly with public communication in the UK. The subsequent House of Commons (2019, p. 69) research report linked the foreign manipulation of political information to the intent to destabilize democratic institutions.

\section{WHAT DO DISSONANT PUBLIC SPHERES MEAN FOR DEMOCRACY?}

As public debate in hybrid media and social networks reinforces the political crisis and as the political crisis reinforces the dissonances in the public sphere, we must deal with a complex array of interactions. Bennett and Livingston (2018, p. 134) labelled the situation as a "new disinformation order", which, in their view, enhances the "decline of democratic institutions" and trust in legacy media, which used to provide authoritative information flows in society. In this situation, dissonant public spheres invoke not only increasing noise levels in public debate but also parallel and alternative communication arenas, which enhance political fragmentation and exclusion. The consolidation of populist movements and their tendency to create their own filter bubbles and frames in separate communication ecologies (Heft et al., 2019) further strengthen the disconnections in the public sphere and threaten democracy. Processes of dealignment and realignment in democratic interfaces can be observed simultaneously with tremendous changes in the communication infrastructure, political information ecologies, and the behavior of audiences. As such, scholars must revisit their theoretical models of political communication and scrutinise their findings (Bennett \& Pfetsch, 2018).

However, general crisis scenarios suffer from difficulties in analy tically separating the causes and effects. Since the consequences for democracy originating in the entanglement of long-term socio-cultural and political changes are hard to separate from the conditions of the changes in communication, one should interpret the situation as a temporary state of development in contemporary democracy and dig deeper to understand the multifaceted picture. In this vain, we may analyze how different groups of actors in democratic societies are affected by the change and how they deal with the technological affordances of digital communication.

Political actors, such as parties, are affected by the multitude of opportunities and arenas for the articulation and processing of public claims. They see that the arenas of communication have inflated due to the availability of new venues, such as feedback tools, comment functions, watch blogs, and active recommendation and ranking systems. The attention economy comes with increasing pressure for ever more engagement in digital communication by political organizations, public administrations, and interest groups. A recent study by Bennett, Segerberg, and Knüpfer (2017) showed that, in dissonant public spheres, the electoral interface between parties and voters is affected by digital technologies. When mainstream parties face increasing decline, the parties on the left and right, in particular, try to develop their organization into connective parties. They use technologies to per- 
form core organizational functions in the electoral arena, yet the operations have been a mixed blessing, and success is not a given. They apply (digital) technologies in their campaigns and canvassing efforts and use the inflated channels in advocating their demands and positions. As such, they contribute to growing discordance, uncertainty, and contradictory expectations.

Political actors, such as governments, have finally realized that digital platforms are not neutral technologies but powerful in their interference into public life and in their treatment of users. In many countries, as well as in the EU, it has been recognized that the Internet industry is commercializing the data of users and, thus, has become an eminent player in the real economy. There are many legal and privacy-related questions involved, as well as the issue of taxation, but suffice to say here that, eventually, governments try to cope with the situation through real (or pretend) efforts to regulate the digital communication industry, as well as shield their citizens from manipulation through digital communication. For instance, in the UK, a recently published House of Commons $(2019$, p. 89 ) report criticized social media companies, stating that they "hide behind the claim of being merely a 'platform"' and deny responsibility for regulating the content of their sites. In order to limit the political power of social media and digital business companies, the report called for the "absolute transparency of online political campaigning [...] indicating the source and the advertiser" (p. 92). Moreover, social media companies were prompted to be "more transparent about their own sites and how they work" (p. 97).

Among the actors most influenced by the hybrid media system are social movements. It has been argued that the transformation of the public sphere through digital media opens up avenues for new voices and social actors who are challenging the political status quo (Papacharissi, 2002). However, this claim does not square with the real inclusion of new actors. Social movements, NGOs, and political activists play a two-fold role, which produces a vicious circle of ever more dissonance. On the one hand, they use digital media to articulate and organize their protests, which increases the polyvocality and plurality of the public sphere. On the other hand, in processing dissonance they stimulate ever more noise. Moreover, digital political action fundamentally changes the character of collective political action. The technology invites spontaneous individualised social action without long-term commitment to a serious cleavage or deep-rooted social cause (Bennett \& Segerberg, 2012). Digital media may replace movement organizations or the collective identities of groups related to the advocacy of a grievance or fundamental values of society.

Finally, the legacy media, which have been the most important and legitimate institutions to organize the flows of public information, opinion formation, and public debate, are confronted with serious and existential challenges. They face shrinking mass media audiences, while publics increasingly mistrust the press (and political institutions). The trends have cascaded as younger generations abstain from legacy media (Banaji \& Cammaerts, 2015; Wonneberger \& Kim, 2017). Audi- 
ences who turn away from legacy media seek more confirming information online (Tsfati \& Ariely, 2014), often fed by social networks. Empowered by network trust, people increasingly believe unknown, anonymous voices over established political actors or media (Quandt, 2012).

In this situation, political and societal actors, as well as the media, must take action and start education initiatives to strengthen digital media literacy. The public needs to know how the contents of digital information ecologies and hybrid media emerge, and users need knowledge and tools to distinguish between quality journalism and disinformation from unreliable sources. However, these calls are also like a drop in the ocean, as we see no short-term relief from the new disinformation order nor the disturbance of democracy.

\section{ACKNOWLEDGMENTS}

This essay rests on the Bellwether lecture, "Digital Dissonance, Disconnection, and Noise and What it Means for Democracy", delivered on February 28th, 2019 at the Oxford Internet Institute and the opening keynote at the international conference, "Comparative Media Studies in Today's World", in Saint Petersburg on April 16, 2019. I thank Curd Knüpfer and Annett Heft for working with me on the ideas and arguments of this essay and further developing them.

\section{REFERENCES}

Abdi-Herrle, S. (2018). Mediale Themensetzung in Zeiten von Web 2.0. Wer beeinflusst wen? Das Agenda-Setting-Verhältnis zwischen Twitter und Online-Leitmedien. Baden-Baden: Nomos.

Altheide, D. L., \& Snow, R. P. (1979). Media Logic. Beverly Hills, CA: Sage.

Altmeppen, K.-D., Bieber, C., Filipovic, A., \& Heesen, J. (2015). Echtzeit-Öffentlichkeiten. Neue digitale Medienordnungen und neue Verantwortungsdimensionen. Communicatio Socialis, 48(4), 382-396.

Banaji, S., \& Cammaerts, B. (2015). Citizens of nowhere land: Youth and news consumption in Europe. Journalism Studies, 16(1), 115-132.

Benkler, Y. (2006). The Wealth of Networks. How Social Production Transforms Markets and Freedom. New Haven, CT: Yale University.

Bennett, W. L., \& Livingston, S. (2018). The disinformation order: Disruptive communication and the decline of democratic institutions. European Journal of Communication, 33(2), 122-139.

Bennett, W. L., \& Pfetsch, B. (2018). Rethinking political communication in a time of disrupted public spheres. Journal of Communication, 68(2), 243-253.

Bennett, W. L., \& Segerberg, A. (2012). The logic of connective action. Digital media and the personalization of contentious politics. Information, Communication \& Society, 15(5), 739-768.

Bennett, W. L., Segerberg, A., \& Knüpfer, C. B. (2017). The democratic interface: Technology, political organization, and diverging patterns of electoral representation. Information Communication and Society, 21(11), 1655-1680.

Berman, J., \& Mulligan, D. K. (2003). Issue advocacy in the age of the internet. In D. M. Anderson \& M. Cornfield (Eds.), The Civic Web: Online Politics and Democratic Values (pp. 77-83). Landham: Rowman \& Littlefield. 
Blumler, J. G. (2013). The fourth age of political communication. Paper presented at the keynote address of the Workshop on Political Communication Online, Freie Universität Berlin.

Blumler, J. G. (2015). Core theories of political communication: Foundational and freshly minted. Communication Theory, 25(4), 426-438.

Blumler, J. G., \& Kanavagh, D. (1999). The third age of political communication: Influences and features. Political Communication, 16(3), 209-230.

Bremer, B., \& Schulte-Cloos, J. (2019). Restructuring British and German party politics in times of crisis. In S. Hutter \& H. Kriesi (Eds.), European Party Politics in Times of Crisis (pp. 281-301). Cambridge-New York, NY: Cambridge University Press.

Bruns, A. (2005). Gatewatching. Collaborative News Production. New York: Peter Lang Publishing.

Chadwick, A. (2011). The political information cycle in a hybrid news system: The British prime minister and the "bullygate" affair. The International Journal of Press/Politics, 16(1), 3-29.

Chadwick, A. (2013). The Hybrid Media System. Politics and Power. Oxford: Oxford University Press.

Dahlgren, P. (2005). The internet, public spheres, and political communication: Dispersion and deliberation. Political Communication, 22(2), 147-162.

Dean, J. (2003). Why the net is not a public sphere. Constellations, 10(1), 95-112.

Downey, J., \& Fenton, N. (2003). New media, counter publicity and the public sphere. New Media \& Society, 5(2), 185-202.

Foa, R. S., \& Mounk, Y. (2016). The danger of deconsolidation: The democratic disconnect. Journal of Democracy, 27(3), 5-17.

Foa, R. S., \& Mounk, Y. (2017). The signs of deconsolidation. Journal of Democracy, 28(1), 5-15.

Fuchs, D., \& Roller, E. (2019). Globalization and political legitimacy in Western Europe. In U. Van Beek (Ed.), Democracy under Threat: A Crisis of Legitimacy? (pp. 221-251). London: Palgrave Macmillan.

Habermas, J. (1996). Between Facts and Norms. Contributions to a Discourse Theory of Law and Democracy. Cambridge: Polity Press.

Habermas, J. (2006). Political communication in media society: Does democracy still enjoy an epistemic dimension? The impact of normative theory on empirical research. Communication Theory, 16(4), 411-426.

Häussler, T. (2019). Civil society, the media and the internet: Changing roles and challenging authorities in digital political communication ecologies. Information, Communication \& Society, Online first, doi: 10.1080/1369118X.2019.1697338.

Heft, A., Mayerhöffer, E., Reinhardt, S., \& Knüpfer, C. (2019). Beyond Breitbart: Comparing right wing digital news infrastructures in six western democracies. Policy \& Internet, Online first, doi: 10.1002/poi3.219.

Hindman, M. (2008). The Myth of Digital Democracy. Princeton, NJ: Princeton University Press.

House of Commons, Digital, Culture, Media and Sport Committee. (2019). Disinformation and 'fake news': Final report. (HC 1791). London: House of Commons.

Hutter, S., \&Kriesi, H. (Eds.) (2019). European Party Politics in Times of Crisis. Cambridge-New York, NY: Cambridge University Press.

Inglehart, R. F, \& Norris, P. (2016). Trump, Brexit, and the Rise of Populism: Economic Have-Nots and Cultural Backlash. Harvard Kennedy School Faculty Research Working Paper Series (TWP16-026).

Kriesi, H. (2019). Conclusion: A critical juncture for the structuration of party systems? In S. Hutter \& H. Kriesi (Eds.), European Party Politics in Times of Crisis (pp. 355-382). Cambridge-New York, NY: Cambridge University Press.

Kriesi, H., \& Hutter, S. (2019). Crisis and the transformation of the national political space in Europe. In S. Hutter \& H. Kriesi (Eds.), European Party Politics in Times of Crisis (pp. 3-32). CambridgeNew York, NY: Cambridge University Press.

Lee, F. L. (2015). Internet, citizen self-mobilisation, and social movement organisations in environmental collective action campaigns: Two Hong Kong cases. Environmental Politics, 24(2), 308-325. 
Messner, M., \& Distaso, M. W. (2008). The source cycle. Journalism Studies, 9(3), 447-463.

Mouffe, C. (2000). Deliberative democracy or agonistic pluralism. In Political Science Series. Vienna: Institute for Advanced Studies.

Napoli, P. M. (2010). Audience Evolution: New Technologies and the Transformation of Media Audiences. New York, NY: Columbia University Press.

Neuberger, C. (2009). Internet, Journalismus und Öffentlichkeit. Analyse des Medienumbruchs. In C. Neuberger, C. Nürnbergk \& M. Rischke (Eds.), Journalismus im Internet (pp. 19-105). Wiesbaden: VSVerlag für Sozialwissenschaften.

Neuberger, C. (2014). Konflikt, Konkurrenz und Kooperation. Interaktionsmodi in einer Theorie der dynamischen Netzwerk öffentlichkeit. Medien \& Kommunikationswissenschaft, 62(4), 567587.

Papacharissi, Z. (2002). The virtual sphere. The internet as a public sphere. New Media \& Society, 4(1), 9-27.

Pfetsch, B., Löblich, M., \& Eilders, C. (2018). Dissonante Öffenltichkeiten als Perspektive kommunikationswissenschaftlicher Theoriebildung. Publizistik, 63(4), 477-495.

Pfetsch, B., Miltner, P., \& Maier, D. (2016). Old and new dynamics of agenda building in a hybrid media system. In G. Vowe \& P. Henn (Eds.), Political Communication in the Online World: Theoretical Approaches and Research Designs (pp. 45-58). New York, NY and Abingdon: Routledge.

Quandt, T. (2012). What's left of trust in a network society? An evolutionary model and critical discussion of trust and societal communication. European Journal of Communication, 27(1), $7-21$.

Sunstein, C. R. (2001). The daily we. Boston Review, 26(3), 1-13.

Toepfl, F., \& Piwoni, E. (2015). Public spheres in interaction: Comment sections of news websites as counter public spaces. Journal of Communication, 65(3), 465-488.

Tsfati, Y., \& Ariely, G. (2014). Individual and contextual correlates of trust in media across 44 countries. Communication Research, 41(6), 760-782.

Van Dijk, J. A. G. M., \& Hacker, K. L. (2018). Internet and Democracy in the Network Society. New York, NY-London: Routledge.

Volkmann, U. (2010). Sekundäre Leistungsrolle. Eine differenzierungstheoretische Einordnung des Prosumenten am Beispiel des "Leser-Reporter". In B. Blättel-Mink \& K. U. Hellmann (Eds.), Prosumer Revisited. Zur Aktualität einer Debatte (pp. 206-220). Wiesbaden: VS Verlag für Sozialwissenschaften.

Waisbord, S. (2016). Disconnections: Media sociology and communication across differences. Paper presented at the Conference of the International Communication Association, Fukuoka, Japan.

Wendelin, M. (2014). Transparenz von Rezeptions und Kommunikationsverhalten im Internet. Theoretische Überlegungen zur Veränderung der Öffentlichkeits dynamiken zwischen Journalismus und Publikum. In W. Loosen \& M. Dohle (Eds.), Journalismus und (sein) Publikum (pp. 73-89). Wiesbaden: VSVerlag für Sozialwissenschaften.

Wonneberger, A., \& Kim, S. J. (2017). TV news exposure of young people in changing viewing environments: A longitudinal, cross-national comparison using people-metre data. International Journal of Communication, 11(22), 72-93. 